\title{
HUBUNGAN JUMLAH PENGUNJUNG DENGAN KUALITAS MIKROBIOLOGI AIR KOLAM RENANG DI DREAM LAND AJIBARANG TAHUN 2016
}

\author{
Uli Amrina Hidayah" ${ }^{1)}$, Yulianto ${ }^{2)}$ \\ Jurusan Kesehatan Lingkungan, Politeknik Kesehatan Kemenkes Semarang, \\ Jl.Raya Baturaden KM 12 Purwokerto, Indonesia
}

\begin{abstract}
Abstrak
Kolam renang adalah suatu usaha umum yang menyediakan tempat untuk berenang, berekreasi serta jasa pelayanan lainnya menggunakan air bersih yang telah diolah.Hasil penelitian ini menyatakan bahwa pemeriksaan angka kuman air yang dilakukan pada hari Senin adalah 43 koloni/ml air dengan jumlah pengunjung 0, pada hari kamis adalah 343 koloni/ml air dengan jumlah pengunjung sebanyak 2 orang dan pada hari Minggu adalah 42.711 koloni/ml air dengan jumlah pengunjung sebanyak 5 orang. Hasil perhitungan hubungan jumlah pengunjung dengan kualitas mikrobiologi air kolam renang di Dream Land Ajibarang menggunakan uji pearson product moment hasilnya adalah nilai $p=0,256(p>0,05)$ sedangkan nilai $r$ atau pearson correlation $=0,920$ ). Hal ini dapat disimpulkan bahwa ada hubungan antara jumlah pengunjung dengan kualitas mikrobiologi air kolam renang di Dream Land Ajibarang tetapi tidak signifikan atau bermakna.Penelitian ini menyarankan melakukan tindakan desinfeksi dengan cara pemberian kaporit pada air kolam renang secara rutin dan pembuatan bak cuci.
\end{abstract}

Kata kunci :(1990-2015) 13 kualitas air kolam renang; -

\begin{abstract}
The Swimming pool is one of general business that provide a swimming pool, recreation place and others good services it using a clean water that has been processed. The result of this research explain that inspection number of bacteria water carried on Monday was 43 colonies $/ \mathrm{ml}$ with the number of visitor as much as 0 people, on Thursday is 343 colonies $/ \mathrm{ml}$ with the number of visitor as much as 2 people and on Monday is about 42.711 colonies $/ \mathrm{ml}$ with the number of visitor as much as 5 people. The results of calculation for the number of visitors related with quality of microbiology pool water in Dream Land Ajibarang using the Pearson product moment test with result is value of $p=0,265(p>0,05)$ meanwhile the value of $r$ or Pearson correlation $=0,920$ ). It can be concluded that there is connection between the numbers of visitors with the quality of microbiology pool water in Dreamland Ajibarang but not significant and meaningful. This research recommend to commit desinfeksi measure using a method by giving chlorine in the pool water regularly and manufacture of washtub.
\end{abstract}

Key Word: (1990 - 2015) 13 the quality of water pool

\section{Pendahuluan}

Kolam renang adalah suatu usaha bagi umum yang menyediakan tempat untuk berenang, berekreasi, berolah raga serta jasa pelayanan lainnya menggunakan air bersih yang telah diolah (Permenkes RI No. 61/MENKES/PER/I/1991).Air kolam renang adalah air di dalam kolam renang yang digunakan untuk olah raga dan kualitasnya memenuhi syarat kesehatan (Permenkes RI No. 416/MENKES/PER/I/1990).

Permenkes RI No. 061/MENKES/PER/I/1991 menyatakan bahwa syarat air kolam renang meliputi fisik yaitu air tidak berbau, jernih dan tidak ada benda terapung. Syarat kimia yaitu aluminium $\leq 0,2$

1) Email : uliamrina40@yahoo.co.id

2) Email : yulianto_61@yahoo.com mg/;, kebasaaan (CaCO3) 50 - 500 mg/l, oksigen terabsorbsi $\leq 1,0 \mathrm{mg} / \mathrm{l}, \mathrm{pH} 6,8-8,5$, sisa chlor $0,2-$ $0,5 \mathrm{mg} / \mathrm{l}$ dan tembaga sebagai $\mathrm{Cu} \leq 1,5 \mathrm{mg} / \mathrm{l}$. Syarat mikrobiologi yaitu angka kuman $\leq 200 \mathrm{koloni} / \mathrm{ml}$ air dan coliform total 0/100 ml air.

Kualitas air kolam renang harus memenuhi syarat kesehatan dan inilah yang sering diabaikan oleh pihak atau pengelola kolam renang. Kolam renang merupakan fasilitas umum sehingga digunakan oleh umum atau orang banyak, tanpa disadari air kolam renang yang tidak memenuhi syarat kesehatan dapat menyebabkan penyakit terhadap pemakainya.Penyakit yang umumnya terjadi adalah iritasi mata dan timbulnya penyakit 
kulit, seperti scabies, dermatitis, dysentri, thypus abdominalis, dan lain-lain.

Penelitian yang dilakukan oleh Yanuar Kuswanto dengan judul penelitian Studi Tentang Kualitas Air Kolam Renang Langen Tirto Purwokerto Kabupaten Banyumas Tahun 2006 pemeriksaan mikrobiologis air kolam renang ratarata mengandung coliform titik A adalah 14, titik B adalah 86, dan titik C adalah 14 per $100 \mathrm{ml}$ air,sehingga dapat disimpulkan bahwa kualitas mikrobiologis di kolam renang tersebut tidak memenuhi syarat kesehatan, karena menurut Permenkes RI No. 61/MENKES/PER/I/1991 tentang Persyaratan Kesehatan Kolam Renang dan Pemandian Umum jumlah coliform total 0/100ml air. Penelitian juga dilakukan oleh Ely Daryati dengan judul Studi Kandungan Bakteri Coliform Air Kolam Renang di Lokawisata Baturaden Kabupaten Banyumas Tahun 2005 pemeriksaan mikrobiologis air kolam renang dilakukan 5 hari. Pada hari pertama di titik A adalah 3,6 per $100 \mathrm{ml}$ air dan titik B adalah 6,1 per $100 \mathrm{ml}$ air. Pada hari kedua di titik A adalah 9,3 per $100 \mathrm{ml}$ dan titik B adalah 9,3 per $100 \mathrm{ml}$. Pada hari ketiga di titik A adalah 2,0 per $100 \mathrm{ml}$ dan titik B adalah 4,0 per $100 \mathrm{ml}$. Pada hari keempat di titik A adalah 7,4 per $100 \mathrm{ml}$ dan titik B adalah 9,3 per $100 \mathrm{ml}$. Pada hari kelima di titik A adalah 6,0 per $100 \mathrm{ml}$ dan titik B adalah 6,8 per $100 \mathrm{ml}$. Pemeriksaan air kolam renang tersebut secara mikrobiologis belum memenuhi syarat karena jumlah coliform lebih dari nol per $100 \mathrm{ml}$ air.

Peneliti ingin melakukan penelitian tentang kualitas mikrobiologi air kolam renang dengan memperhatikan jumlah pengunjung yang datang dan menggunakan kolam renang.Jumlah pengunjung kolam renang juga merupakan salah satu faktor yang menyebabkan adanya keberadaan kuman pada air kolam renang. Jumlah pengunjung rata-rata di kolam renang Dream Land Ajibarang, pada hari biasa (Senin-Sabtu) \pm 100-300 pengunjung, sedangkan pada hari libur (Minggu/libur nasional) \pm 2000-3000 pengunjung. Judul KTI yang akan peneliti lakukan adalah Hubungan Jumlah Pengunjung dengan Kualitas Mikrobiologi Air Kolam Renang di Dream Land Ajibarang Tahun 2016. Tujuan penelitian ini adalah untuk mengetahui hubungan jumlah pengunjung dengan kualitas mikrobiologi air kolam renang di Dream Land Ajibarang tahun 2016.

Tujuan umum dai penelitian ini adalah untuk mengetahui hubungan antara jumlah pengunjung dengan kualitas mikrobiologi air kolam renang di Dream Land Ajibarang tahun 2016. Tujuan khusus diantaranya :

a. Menghitung jumlah pengunjung kolam renang di Dream Land Ajibarang. b. Mengukur kualitas mikrobiologis air kolam renang di Dream Land Ajibarang.

c. Menganalisis hubungan jumlah pengunjung dengan kualitas mikrobiologi air kolam renang di Dream Land Ajibarang.

\section{Metode Penelitian}

Jenis penelitian yang di gunakan adalah observasional dengan pendekatan crossectional.Lokasi penelitian adalah kolam renang Dream Land Ajibarang di desa Pancasan kecamatan Ajibarang kabupaten Banyumas. Penelitian ini dilakukan pada bulan Juni 2016.Penelitian dilakukan dengan maksud untuk mengukur atau memeriksa kualitas mikrobiolgi air kolam renang di Dream Land Ajibarang tahun 2016.

Populasi penelitian ini adalah seluruh air kolam renang dan jumlah pengunjung di Dream Land Ajibarang.Sampel pada penelitian ini adalah air dan jumlah pengunjung kolam renang segi enam di Dream Land Ajibarang.Peneliti menggunakan purposive sampling dengan mempertimbangkan air kolam renang tidak didesinfeksi secara rutin dan kolam renang segi enam terdapat wahana air, yaitu ember tumpah dan papan seluncur. Cara pengumpulan data penelitian adalah melakukan penghitungan jumlah pengunjung dan pengukuran atau pemeriksaan kualitas mikrobiologi air kolam renang (angka kuman) yang dilakukan oleh peneliti dan petugas laboratorium.

\section{Hasil dan Pembahasan}

\section{A. Data Umum}

1. Lokasi Dream Land Ajibarang Obyek wisata Dream Land terletak di Desa Pancasan, Kecamatan Ajibarang, Kabupaten Banyumas.Obyek wisata ini dapat ditempuh tidak jauh dari terminal Ajibarang, atau sebelah selatan dari terminal Ajibarang sekitar $1 \mathrm{~km}$.

Batas-batas geografis obyek wisata Dream Land adalah sebagai berikut:

$$
\begin{array}{ll}
\text { - } & \text { Sebelah } \\
\multicolumn{1}{c}{\text { :PerumahanPenduduk }} \\
\text { - } & \text { Sebelah Timur :JalanRaya Pancasan } \\
\text { - } & \text { Sebelah Selatan : Sungai Tajum } \\
\text { - } & \text { Sebelah Barat : Lahan Pekarangan } \\
& \text { dan Perumahan Penduduk }
\end{array}
$$

Dream Land sebelum dibangun sebagai tempat wisata, awal mulanya adalah sebuah pabrik tapioka, peninggalan zaman Belanda sekitar tahun 1819, karena perkembangan pariwisata dewasa ini semakin meningkat dan belum ada tempat wisata keluarga yang sangat memadai, terutama dengan konsep taman air (water 
park), maka dibangunlah kawasan wisata Dream Land dengan luas wilayah tanah 7,8 Ha.

Pemilik Dream Land adalah Bapak Wastam Sariyadi, SE sebagai pemilik tunggal.Dream Land dibangun pada tahun 2010 dan resmi dibuka sejak 24 Februari 2011.

2. Fasilitas Dream Land Ajibarang

\section{a. Kolam Renang}

Tersedia 9 kolam renang dengan berbagai ukuran dan kedalaman yaitu kolam lumba-lumba, kolam oval, kolam mozaik, kolam paud, kolam ombak, kolam bulus, kolam segi 6, kolam besar dan kolam olimpic.

b. Wahana Permainan

c. Flying Fox

d. Bioskop 4 Dimensi

e. Taman Reptil

f. Taman Buaya

g. Taman Unggas

h. Taman Batu

i. Rumah Aquarium

j. Terapi Ikan

3. Operasional Kolam Renang

Kolam renang beroperasi dari pukul 08.00 WIB sampai pukul16.00 WIB dengan harga tiket masuk dewasa hari Senin s/d Sabtu Rp. 20.000, hari Minggu dan hari libur Rp. 25.000. Anak-anak dibawah 5 tahun Rp. 5.000 diatas 5 tahun sudah dihitung dewasa. Jumlah pengunjung rata-rata di kolam renang Dream Land Ajibarang, pada hari biasa (Senin-Sabtu) \pm 100-300 pengunjung, sedangkan pada hari libur (Minggu/libur nasional) \pm 2000-3000 pengunjung. Pengunjung kolam renang Dream Land Ajibarang sangat beragam, mulai dari anak-anak, dewasa, laki-laki maupun perempuan.Pengguna kolam renang Dream Land Ajibarang 60\% adalah anak-anak, karena banyak wahana permainan yang disediakan oleh pihak Dream Land untuk anak-anak.

4. Kondisi Kolam Renang

Hasil observasi yang peneliti lakukan di kolam renang Dream Land Ajibarang adalah konstruksi kolam renang segi enam Dream Land Ajibarang memiliki lantai yang kuat terbuat dari keramik, kedap air, permukaannya rata, berwarna terang, dindingnya kuat, permukaan dinding rata, sudut pada dasar kolam tidak melengkung, tidak terjadi hubungan langsung air bersih dan air kotor, terdapat 3 lubang pengurasan, lantai ditepi kolam kedap air, lebar lantai pinggir kolam $1 \mathrm{~m}$, terdapat wahana papan seluncur dan ember tumpah yang aman bagi pengunjung. Menurut PermenkesRI No. 061/MENKES/PER/I/1991 tentang Persyaratan Kesehatan Kolam Renang dan Pemandian Umumbahwa kolam renang harus memiliki lantai yang kuat, lantai kedap air, permukaan rata, lantai berwarna terang, dindingnya kuat, kedap air, permukaannya rata, sudut pada dasar kolam melengkung/conus, tidak terjadi hubungan langsung air bersih dan air kotor, lubang pengurasan dilengkapi jeruji besi, terdapat tangga dipinggir kolam, lantai tepi kolam kedap air, lebar lantai pinggir kolam $1 \mathrm{~m}$, ada tanda yang jelas tentang kedalaman kolam, tidak terdapat papan loncat. Berdasarkan hasil pengamatan, konstruksi kolam renang yang belum memenuhi syarat adalah sudut pada dasar kolam tidak melengkung/conus dan lubang pengurasan tidak dilengkapi dengan jeruji besi.Sebaiknya pihak atau pengelola kolam renang membuat sudut kolam renang melengkung/conus dan lubang pengurasan dilengkapi jeruji besi untuk menghindari adanya hubungan langsung antara air kotor dan air bersih pada kolam renang.Kebersihan kolam renang sudah baik dan terjaga.Seluruh petugas kolam renang saling menjaga kebersihan kolam maupun lingkungan sekitar kolam renang demi kenyamanan pengunjung. Hal ini merupakan poin bagi pihak Dream Land Ajibarang apabila pengunjung yang datang merasa nyaman, maka akan secara otomatis terpromosikan kepada orang lain tentang kenyamanan yang diperoleh di obyek wisata Dream Land Ajibarang.

5. Kondisi Air Kolam Renang

a. Sumber Air Bersih

Sumber air kolam renang di Dream Land Ajibarang adalah dari mata air.Terdapat 3 tempat mata air yang terletak di kawasan obyek wisata Dream Land Ajibarang yang dibatasi dengan tembok yang tinggi, sehingga tidak bercampur dengan kawasan wisata Dream Land.Sistem distribusi air dikolam renang Dream Land Ajibarang menggunakan sistem perpipaan. Air yang sudah di tempung ke tempat penampungan kemudian di 
alirkan ke dalam kolam renang dan fasilitas yang ada di kolam renang Dream Land Ajibarangseperti : toilet, pancuran bilas, cafe, dan lain-lain. Secara fisik air yang diambil dari mata air tersebut jernih dan tidak mengandung banyak kotoran atau benda terapungakan tetapi, pengawasan terhadap kualitas air kolam renang tetap perlu diperhatikan seperti pemberian desinfektan atau kaporit untuk menjaga kebersihan dan kesterilan air kolam renang tersebut.

b. Kualitas Fisik Air Kolam Renang

Kualitas fisik air kolam renang memiliki persyaratan kesehatan.Berdasarkan Permenkes RI No. 061/MENKES/PER/I/1991 tentang Persyaratan Kesehatan Kolam Renang dan Pemandian Umum. Air kolam renang harus memenuhi syarat :

1) Bau, bebas dari bau yang mengganggu.

2) Benda terapung, bebas dari benda terapung.

3) Kejernihan, diukur menggunakan piringan seichi disk.

Hasil pemeriksaan air kolam renang di Dream Land Ajibarang adalah tidak berbau, jernih dan tidak terdapat benda terapung.Sehingga, air kolam renang di Dream Land Ajbarang memenuhi syarat kualitas fisik air kolam renang.Petugas membersikan kolam renang dari benda-benda terapung menggunakan jaring-jaring khusus yang dapat menangkap benda terapung tersebut.Pembersihan dilakukan pagi hari sebelum kolam renang digunakan, pada saat kolam digunakan dan pengunjung tidak terlalu banyak, serta sore hari setelah kolam renang digunakan.

Pengawasan kualitas air kolam renang tidak dilakukan secara berkala. Berdasarkan wawancara dengan pihak pengelola, tidak dilakukan pemeriksaan air kolam renang baik secara kimia maupun mikrobiologis.Desinfeksi atau klorinasi pada air kolam renang juga tidak dilakukan, karena air kolam renang secara kualitas fisik sudah baik sehingga dianggap air kolam renang sudah memenuhi syarat.
Diharapkan kepada pihak pengelola kolam renang Dream Land Ajibarang dapat melakukan desinfeksi atau klorinasi dengan memberikan kaporit untuk mendesinfeksi air kolam renang dan melakukan pemeriksaan kualitas air kolam renang secara rutin untuk mengetahui kualitas air kolam renang, baik secara fisik, kimia dan mikrobiologi. Kualitas air kolam renang dapat mempengaruhi pengunjung yang menggunakan kolam renang. Air kolam renang yang tidak memenuhi syarat kesehatan mampu menularkan penyakit atau mengkontaminasi pengunjung yang menggunakan air kolam renang yang tidak memenuhi syarat kesehatan.

6. Sarana Pendukung Kolam Renang Sarana pendukung kolam renang Dream Land Ajibarang sebagai berikut :

Tabel 4.1 Sarana Pendukung Kolam Renang Dream Land Ajibarang

\begin{tabular}{llll}
\hline No. & Fasilitas & Jumlah & Kondisi \\
\hline 1. & $\begin{array}{l}\text { Kamar ganti, } \\
\text { toilet atau } \\
\text { kamar bilas }\end{array}$ & Baik \\
\hline 2. & Pancuran bilas & 2 & Baik \\
\hline 3. & $\begin{array}{l}\text { Tempat } \\
\text { penitipan } \\
\text { barang/loker }\end{array}$ & 100 & Baik \\
\hline 4. & Papan luncur & 12 & Baik \\
\hline 5. & Ember tumpah & 5 & Baik \\
\hline 6. & Gazebo & 20 & Baik \\
\hline \&. & Cafetaria & 1 & Baik \\
\hline 1. & & &
\end{tabular}

Hasil tabel 4.1 sarana pendukung kolamrenang sudah memenuhi persyaratan. Namun, sebaiknya adanya aturan pemisahan yang jelas antara pengguna kamar ganti, toilet atau kamar bilas bagi wanita dan pria.Hal ini mempertimbangkan nilai moral dan kenyamanan. Berdasarkan hasil pengamatan, kolam renang di Dream Land Ajibarang juga tidak menyediakan tempat cuci tangan, sebaiknya pengelola atau pihak Dream Land Ajibarang menyediakan tempat cuci tangan yang dilengkapi dengan sabun, pengerin tangan dan cermin. Tempat cuci tangan sebaiknya terletak di tempat yang mudah dijangkau dan berdekatan dengan jamban peturasan dan kamar ganti pakaian untuk 
memudahkan pengunjung dalam menggunakan tempat cuci tangan.Fungsi tempat cuci tangan ini adalah untuk membersihkan tangan sehingga dapat mencegah adanya kontaminasi dari tangan pengunjung ke air kolam renang.

Kolam renang Dream Land Ajibarang tidak terdapat bak cuci kaki. Berdasarkan PermenkesRI

No. 061/MENKES/PER/I/1991 perlu adanya bak cuci kaki di kolam renang. Syarat bak cuci kaki dengan ukuran 1,5 m x 1,5 m x $20 \mathrm{~cm}$. Bak terisi penuh dengan air dan kadar sisa chlor 2 ppm. Fungsi dari bak cuci kaki adalah untuk mendesinfeksi kaki pengunjung sebelum masuk ke dalam kolam renang dan untuk mencegah kontaminasi atau penularan penyakit yang disebabkan oleh kaki pengunjung yang tidak memasukan ke dalam bak cuci kaki.Diharapkan pengelola obyek wisata Dream Land Ajibarang membuat atau menyediakan bak cuci kaki yang memenuhi syarat.Di kolam renang Dream Land Ajibarang tidak melakukan desinfeksi atau klorinasi dengan pemberian kaporit pada air kolam renang. Sebaiknya apabila membuat bak cuci kaki diharapkan memberikan chlor ke dalam air bak cuci kaki dengan kadar sisa chlor 2 ppm.

\section{B. Data Khusus}

1. Pengambilan Sampel Air Kolam Renang

Pengambilan sampel air dilakukan pada bulan puasa hari Minggu, Senin dan Kamis pada tanggal 12,13 dan 16 Juni 2016. Sampel air diambil sebelum digunakan dan sesudah digunakan. Pengambilan sampel dilakukan pada bulan puasa sehingga pengambilan sampel pukul 07.00 dan pukul 13.00, hal ini berbeda dengan jam operasional biasanya, karena pada bulan puasa jumlah pengunjung sedikit sehingga menjelang siangpun tidak terdapat pengunjung. Pengambilan sampel air yang peneliti lakukan di kolam renang segi enam. Peneliti memilih kolam segi enam karena kolam tersebut banyak digunakan atau diminati pengunjung untuk berenang dan terdapat banyak wahana air di kolam renang tersebut.

Penelitian ini menghitung jumlah pengunjung yang masuk ke kolam renang dan mengukur atau memerriksa kualitas mikrobiologi air kolam renang tersebut.Pengambilan sampel air kolam renang ini bertujuan untuk memeriksa angka kuman pada air kolam renang.Hal ini untuk mengetahui adanya pengunjung mampu meningkatkan angka kuman air kolam renang ataupun tidak. Cara penghitungan jumlah pengunjung adalah satu orang yang masuk ke kolam renang dihitung satu pengunjung, walaupun pengunjung tersebut keluar masuk kolam renang dalam satu hari ,tetap dihitung satu pengunjung.

2. Hasil Pemeriksaan Angka Kuman Air Kolam Renang di Dream Land Ajibarang Tabel 4.2 Hasil Pemeriksaan Angka Kuman di Dream Land Ajibarang

\begin{tabular}{|c|c|c|c|c|}
\hline $\begin{array}{c}\text { Waktu } \\
\text { Pe- } \\
\text { ngam- } \\
\text { bilan }\end{array}$ & $\begin{array}{c}\text { Hasil } \\
\text { Peme- } \\
\text { riksaan }\end{array}$ & $\begin{array}{l}\text { Hasil } \\
\text { Rata - } \\
\text { rata }\end{array}$ & $\begin{array}{c}\text { Hasil } \\
\text { Seli- } \\
\text { sih } \\
\text { Ang- } \\
\text { ka } \\
\text { Ku- } \\
\text { man }\end{array}$ & $\begin{array}{r}\text { Stan- } \\
\text { dar } \\
\text { Ket. }\end{array}$ \\
\hline \multirow{3}{*}{$\begin{array}{c}\text { Ming- } \\
\text { gu } \\
\text { Pagi }\end{array}$} & 926 & \multirow{3}{*}{839} & \multirow{6}{*}{42711} & \multirow{6}{*}{ TMS } \\
\hline & 654 & & & \\
\hline & 936 & & & \\
\hline \multirow{3}{*}{$\begin{array}{l}\text { Ming- } \\
\text { gu } \\
\text { Siang }\end{array}$} & 24.600 & \multirow{3}{*}{$\begin{array}{c}43.55 \\
0\end{array}$} & & \\
\hline & 52.950 & & & \\
\hline & 53.100 & & & \\
\hline \multirow{3}{*}{$\begin{array}{c}\text { Senin } \\
\text { Pagi }\end{array}$} & 590 & \multirow{3}{*}{1.293} & \multirow{6}{*}{342} & \multirow{6}{*}{ TMS } \\
\hline & 1.560 & & & \\
\hline & 1.730 & & & \\
\hline \multirow{3}{*}{$\begin{array}{l}\text { Senin } \\
\text { Siang }\end{array}$} & 700 & \multirow{3}{*}{1250} & & \\
\hline & 1.850 & & & \\
\hline & 1.200 & & & \\
\hline \multirow{3}{*}{$\begin{array}{c}\text { Kamis } \\
\text { Pagi }\end{array}$} & 915 & \multirow{3}{*}{1130} & \multirow{6}{*}{43} & \multirow{6}{*}{ MS } \\
\hline & 1.010 & & & \\
\hline & 1.465 & & & \\
\hline \multirow{4}{*}{$\begin{array}{c}\text { Kamis } \\
\text { Siang }\end{array}$} & 755 & \multirow{3}{*}{1871} & & \\
\hline & 870 & & & \\
\hline & 740 & & & \\
\hline & Mean & & 143 & 5,33 \\
\hline Standa & rd Error o & Mean & 1417 & ,096 \\
\hline $\mathrm{a}$ & Range & & 42 & \\
\hline $\begin{array}{l}\text { S } \\
\mathrm{i}\end{array}$ & Minimum & & & \\
\hline$T$ & Maximum & & 42 & \\
\hline $\begin{array}{l}\mathrm{P} \\
\text { Pemeril }\end{array}$ & saan an & ka ku & tan & kukan \\
\hline
\end{tabular}


sebelum dan sesudah kolam renang digunakan. Satu sampel diperiksa 3 kali, hal ini untuk mendapatkan hasil yang valid atau sebenarnya. Hasil akhir penghitungan angka kuman diperoleh dari jumlah rata-rata tiga kali pemeriksaan, kemudian hasil penghitungan diperoleh dari selisih angka kuman sebelum dan sesudah digunakan (siang - pagi) sehingga hasil pemeriksaan angka kuman adalah pada hari Senin sebesar 43 koloni/ml air, hari Kamis sebesar $343 \mathrm{koloni} / \mathrm{ml}$ air dan hari Minggu sebesar $42.711 \mathrm{koloni} / \mathrm{ml}$ air. Hasil analisis statistik angka kuman diperoleh mean 14365,33, standard error of mean 14173,096.Menurut Permenkes RI No. 61/MENKES/PER/I/1991 tentang Persyaratan Kesehatan Kolam Renang dan Pemandian Umum persyaratan angka kuman adalah $\leq 200 / \mathrm{ml}$ air, sehingga air kolam renang di Dream Land Ajibarang pada hari Senin memenuhi syarat, sedangkan pada hari Kamis dan Minggu tidak memenuhi syarat. Faktor yang mempengaruhi kualitas mikrobiologi air kolam renang diantaranya desinfeksi, sumber air, kondisi kolam renang, pengunjung dan pengawasan kolam renang.

Faktor yang mempengaruhi angka kuman tinggi diantaranya di kolam renang Dream Land Ajibarang tidak dilakukannya desinfeksi.Menurut pengelola kolam renang, kualitas air yang bersih dan jernih dianggap sudah memenuhi syarat sebagai air kolam renang yang memenuhi syarat kesehatan. Berdasarkan Permenkes RI No. 61/MENKES/PER/I/1991 tentang Persyaratan Kesehatan Kolam Renang dan Pemandian Umum terdapat aturan atau syarat kualitas air kolam renang baik secara fisik, kimia dan mikrobiologi yang harus di taati oleh pengelola kolam renang, karena hal ini dapat mempengaruhi kondisi kesehatan bagi pengunjung kolam renang.

Faktor lain yang mempengaruhi kualitas mikrobiologi air kolam renang :

a. Tidak tersedianya bak cuci kaki hal ini menjadi faktor penting karena kaki pengunjung yang tidak steril dapat mempengaruhi kualitas mikrobiologi air kolam renang.

b. Perilaku pengunjung yang tidak membilas terlebih dahulu sebelum masuk kolam renang dapat mempengaruhi kualitas mikrobiologi air kolam renang.

Kuman yang masuk kedalam kolam renang dapat dipengaruhi karena kondisi pengunjung yang tidak steril atau kuman sudah ada pada pengunjung sendiri sehingga kuman mencemari air kolam renang.

3. Perhitungan Jumlah Pengunjung Kolam Renang di Dream Land Ajibarang Tabel 4.3 Jumlah Pengunjung di Dream Land Ajibarang

\begin{tabular}{cc}
\hline Hari & Jumlah Pengunjung \\
\hline Senin & 0 \\
\hline Kamis & 2 \\
\hline Minggu & 5 \\
\hline Mean & 2,33 \\
\hline $\begin{array}{c}\text { Standard Error of } \\
\text { Mean }\end{array}$ & 1,453 \\
\hline Range & 5 \\
\hline Minimum & 0 \\
\hline Maximum & 5
\end{tabular}

Hasil tabel 4.3 jumlah pengunjung pada hari Minggu sebanyak 5 orang, Senin tidak ada pengunjung dan hari Kamis sebanyak 2 orang.Pengunjung Dream Land pada bulan puasa sangatlah sedikit dibandingkan dengan hari-hari biasa. Hasil analisis statistik jumlah pengunjung diperoleh mean 2,33, standard error of mean 1,453. Pengunjung sangatlah sedikit dibandingkan dengan hari-hari biasa karena penelitian dilakukan pada bulan puasa. Peneliti juga ingin mengetahui dengan jumlah pengunjung yang sedikit, kualitas mikrobiologi air kolam renang (angka kuman) memenuhi syarat atau tidak memenuhi syarat.Pemeriksaan angka kuman pada air kolam renang adalah selisih pemeriksaan sebelum dan sesudah air kolam renang segi enam digunakan.

4. Hasil Pengukuran $\mathrm{pH}$ Kolam Renang di Dream Land Ajibarang

Tabel 4.4 Hasil Pengukuran pH di Dream Land Ajibarang

\begin{tabular}{lll}
\hline No & Hari & Ph \\
\hline 1 & Senin & 7 \\
\hline 2 & Kamis & 7 \\
\hline 3 & Minggu & 5 \\
\hline
\end{tabular}

Hasil tabel 4.4 pemeriksaan $\mathrm{pH}$ air kolam renang pada hari Senin 7 , hari Kamis 7 dan hari Minggu 5.Berdasarkan Permenkes RI No. 
61/MENKES/PER/I/1991 tentang Persyaratan Kesehatan Kolam Renang dan Pemandian Umum, pH (derajat keasaman) berkisar 6,8 - 8,5. Hal ini menunjukkan $\mathrm{pH}$ air kolam renang pada hari Senin dan Kamis memenuhi syarat sedangkan pada hari Minggu tidak memenuhi syarat.Pada hari Minggu didapatkan hasil pengukuran dengan $\mathrm{pH}$ yang asam, hal ini disebabkan pada hari minggu turun hujan atau gerimis sehingga $\mathrm{pH}$ air kolam renang tersebut menjadi rendah atau asam.

5. Hubungan Jumlah Pengunjung dengan Kualitas Mikrobiologi Air Kolam Renang di Dream Land Ajibarang

Hasil perhitungan hubungan jumlah pengunjung dengan kualitas mirobiologi air kolam renang (angka kuman) menggunakan uji pearson product moment hasilnya adalah nilai $\mathrm{p}=0,256$ ( $>0,05)$ atau Ho diterima sedangkan nilai $\mathrm{r}$ atau pearson correlation $=0,920$ (kategori hubungan kuat) atau ada hubungan. Hal ini dapat disimpulkan bahwa ada hubungan antara jumlah pengunjung dengan kualitas mikrobiologi air kolam renang di Dream Land Ajibarang tetapi tidak signifikan atau bermakna. Hal ini disebabkan karena jumlah pengunjung yang sedikit.Nilai $r$ atau pearson correlation $=0,920$. Jika nilai $\mathrm{r}$ atau pearson correlation $=0$ dapat disimpulkan bahwa tidak ada hubungan.

Penelitian ini memperhatikan jumlah pengunjung menjadi salah faktor tingginya angka kuman air, tetapi tidak signifikan atau bermakna.Hal ini disebabkan karena jumlah pengunjung yang sangat sedikit. Pengambilan sampel air kolam renang dilakukan di bulan puasa sehingga jumlah pengunjung tidak banyak atau tidak seperti pada hari - hari biasa. Faktor lain yang dapat menyebabkan tingginya angka kuman pada air kolam renang :

a. Tidak dilakukannya desinfeksi atau klorinasi sehingga angka kuman air kolam renang menjadi tinggi.

b. Tidak adanya bak cuci kaki. Hal ini dapat mempengaruhi kualitas air kolam renang, fungsi dari bak cuci kaki adalah untuk mendesinfeksi kaki pengunjung sebelum masuk ke dalam kolam renang dan untuk mencegah kontaminasi atau penularan penyakit yang disebabkan oleh kaki pengunjung yang tidak memasukan ke dalam bak cuci kaki.

c. Perilaku pengunjung yang tidak melakukan pembilasan sebelum masuk ke kolam renang juga dapat mempengaruhi kualitas mikrobiologi air kolam renang. Pengunjung yang melakukan kencing, meludah didalam kolam renang juga mampu mempengaruhi kualitas mikrobiologi air kolam renang.

d. Kondisi kesehatan mempengaruhi kualitas air, seperti penyakit gatal mampu menularkan penyakit ke pengunjung lain dengan media air kolam renang tersebut.

6. Keterbatasan Penelitian

Penelitian ini memiliki keterbatasan penelitian, antara lain :

a. Jumlah pengunjung sedikit karena peneliti melakukan penelitian di bulan puasa, hal ini tentu berbeda dengan jumlah pengunjung pada saat hari biasa atau diluar bulan puasa. Untuk penelitian selanjutnya dapat dilakukan pengambilan sampel air kolam renang pada hari-hari biasa atau diluar bulan puasa untuk mendapatkan data yang valid atau sebenarnya.

b. Tidak mengetahui kondisi kesehatan pengunjung kolam renang. Peneliti tidak menanyakan kepada pengunjung kolam renang di Dream Land Ajibarang, contohnya adalah pengunjung mempunyai riwayat penyakit gatal atau kulit. Hal ini disebabkan karena peneliti menerapkan nilai etika atau sopan santun. Kolam renang Dream Land Ajibarang tidak memasang peraturan atau himbauan kepada pengunjung kolam renang yang mempunyai penyakit kulit dan membilas tubuh sebelum dan sesudah berenang. Untuk penelitian selanjutnya dapat dilakukan pengambilan data tentang kondisi kesehatan pengunjung untuk mengetahui adanya pengaruh kondisi kesehatan pengunjung dengan kualitas mkrobiologi air kolam renang.

\section{Simpulan dan Saran}

A. Simpulan

1. Jumlah pengunjung kolam renang Dream Land Ajibarang pada penelitian yang dilakukan adalah 0, 2 dan 5 orang. 
2. Hasil pemeriksaan angka kuman air kolam renang pada penelitian yang dilakukan adalah $43 \mathrm{koloni} / \mathrm{ml}$ air (memenuhi syarat), $342 \mathrm{koloni} / \mathrm{ml}$ air (tidak memenuhi syarat), $42.711 \mathrm{koloni} / \mathrm{ml}$ air (tidak memenuhi syarat). Pemeriksaan secara kimia $\mathrm{pH}$ nya adalah 7 (memenuhi syarat), 7 (memenuhi syarat) dan 5 (tidak memenuhi syarat).

3. Ada hubungan antara jumlah pengunjung dengan kualitas mikrobiologi air kolam renang di Dream Land Ajibarang tetapi tidak signifikan atau bermakna karena nilai $\mathrm{r}$ atau pearson correlation $=0,920$.

B. Saran

1. Dinas Kesehatan Kabupaten Banyumas Menjadi bahan masukan bagi Dinas Kesehatan Kabupaten Banyumas dalam pengambilan keputusan berkaitan dengan upaya peningkatan kualitas air kolam renang.Seperti memberikan teguran apabila ditemukan angka kuman yang tinggi pada air kolam renang di wilayah Kabupaten Banyumas.

2. Bagi Pihak atau Pengelola Kolam Renang Pengelola atau pihak Dream Land melakukan desinfeksi dan pemeriksaan secara rutin yang mengacu pada persyaratan yang ada dan membuat atau menyediakan bak cuci kaki agar kualitas air khususnya mikrobiologi memenuhi syarat untuk menekan dan mencegah penyakit yang ditimbulkan karena kualitas air kolam renang yang tidak memenuhi syarat.

3. Bagi pengunjung

Sebelum masuk ke kolam renang untuk membilas tubuhnya terlebih dahulu agar menghindari kontaminasi dan penularan penyakit melalui kolam renang.

\section{DAFTAR PUSTAKA}

Aris Santjaka, 2011, Statistik Untuk Penelitian Kesehatan, Yogyakarta: Nuha Medika.

Departemen Kesehatan RI. Direktorat Jenderal Pemberantasan Penyakit Menular dan Penyehatan Lingkungan Pemukiman, 1992, Modul pelatihan perbaikan kualitas air : bagi petugas pembinaan kesehatan lingkungan seDati II, Jakarta: Departemen Kesehatan.

Departemen Kesehatan RI. Direktorat Jenderal Pemberantasan Penyakit Menular dan
Penyehatan Lingkungan Permukiman, 1998, Pedoman Pelatihan Water Test Kit Sistem Membran Filter : bagi petugas sanitasi kecamatan, Jakarta: Departemen Kesehatan.

Departemen Kesehatan RI. Permenkes RI No.416/MENKES/PER/IX/1990 tentang Syarat-syarat dan Pengawasan Kualitas Air, Jakarta.

Departemen Kesehatan RI. Permenkes RI No.61/MENKES/PER/I/1991 tentang persyaratan kesehatan kolam renang dan pemandian umum, Jakarta.

Ely Daryati, 2005, Studi Kandungan Bakteri Coliform Air Kolam Renang di Lokawisata Baturaden Kabupaten Banyumas Tahun 2005, KTI, Purwokerto:Program Studi DIII Kesehatan Lingkungan Poltekkes Kemenkes Semarang.

Indah Werdiningsih, 2013, Praktikum Mikrobiologi Pemeriksaan Angka Kuman Pada Makanan Dan Minuman Dengan Metode Pour Plate. Poltekkes Kemenkes Yogyakarta.

Kencana Handayani, 2015, Pengukuran Kadar Sisa Chlor Sebelum dan Sesudah Pemakaian Air Kolam Renang di Water Park Surya Yudha Kabupaten Banjarnegara tahun 2015, KTI, Purwokerto: Program Studi DIII Kesehatan Lingkungan Poltekkes Kemenkes Semarang.

Srikandi Fardiaz, 1992, Polusi Air \& Udara, Yogyakarta: Kanisius (Anggota IKAPI).

Suparlan, 2012, Pengantar Pengawasan HygieneSanitasi Tempat-Tempat Umum - Wisata \& Usaha-Usaha Untuk Umum, Surabaya: Percetakan Duatujuh.

Suparlan, 2012, Pengantar Pengawasan HygieneSanitasi Tempat-Tempat Umum - Wisata \& Usaha-Usaha Untuk Umum, Surabaya: Percetakan Duatujuh.

Suparmin, 2003, Kimia Untuk Air Dan Air Limbah, Politeknik Kesehatan Semarang Jurusan Kesehatan Lingkungan Purwokerto.

Totok Sutrisno, dkk. 2006, Teknologi Penyediaan Air Bersih, Jakarta: PT Rineka Cipta. 